\title{
The Microbial Quality of Raw Milk from four locations in Abia State, Nigeria
}

\author{
Edward, K.C. and Inya, I.M. \\ Department of Microbiology, Michael Okpara University of Agriculture, Umudike, Nigeria
}

\begin{abstract}
The microbiological quality of raw milk from four locations (Umudike, Lokpa, Umuahia and Aba) in Abia State, Nigeria was investigated. The result of the different counts showed that the Umudike sample gave the lowest Total Heterotrophic count (THC) of $9.88 \times 10^{7} \mathrm{cfu} / \mathrm{ml}$ while the Lokpa sample gave the highest THC of $1.26 \times 10^{8} \mathrm{cfu} / \mathrm{ml}$. The coliform count ranged from $5.40 \times 10^{6} \mathrm{cfu} / \mathrm{ml}$ to $9.50 \times 10^{6} \mathrm{cfu} / \mathrm{ml}$ with the lowest count from Umudike while Lokpa sample recorded the highest count. The staphylococcal count had the highest and lowest counts to be $1.0^{7} \times 10^{8} \mathrm{cfu} / \mathrm{ml}$ (Lokpa sample) and $6.70 \times 10^{7} \mathrm{cf} / \mathrm{ml}$ (Umudike sample) respectively. The fungal count ranged between $6.40 \times 10^{7}$ and $9.20 \times 10^{7} \mathrm{cfu} / \mathrm{ml}$ with Aba sample being the lowest and Lokpa sample being the highest. The bacterial isolates include Escherichia coli, Streptococcus spp, Staphylococcus aureus, while the fungal isolates were Candida spp and Mucor spp. The results indicated poor hygienic standard of raw milk from uncontrolled environments and the increased public health risk of those consuming raw milk from such uncontrolled sources.
\end{abstract}

Keywords: Aba, Lokpa, Microbiological quality, Umuahia, Umudike, raw milk

\section{Introduction}

Milk is the fluid normally secreted by female mammals for the nourishment of their young ones. It is a compulsory part of daily diet for the expectant mothers as well as growing children (1). Milk provides a near perfect diet for most young animals and in most cases forms the sole source of diets for most mammals in their first few weeks or months of life.

Milk is one of the complete foods which there seems to be no adequate substitute. Milk has good quality protein and is a unique substance in that it is consumed as fluid milk with minimal processing and also it is the raw material used to manufacture a wide variety of products (2). Milk may be modified by condensing, drying, flavouring, fortifying, demineralization and other treatments (3).

The principal components of milk are water, fat, protein and lactose. Typically, bovine milk is composed of approximately $3.7 \%$ fat, $3.2 \%$ protein, $4.8 \%$ lactose, $0.19 \%$ non protein nitrogen and $0.7 \%$ ash. However, the exact composition of bovine milk varies with individual animals, breed, season, diet and phase of lactation (4)

It starts its journey in the udder of a mammal as a sterile substance, but as it passes out of the teat, it is inoculated by the animal's normal flora (5). Being a nutritionally balanced food stuff with a low microbial load (less than $10000 \mathrm{ml}^{-1}$ ) when drawn from the udder of a healthy cow, milk gets contaminated at various stages including the cow itself, the milker (manual as well as automated) i.e. the milker's hand or milking equipment, storage vessels and water supply particularly when used for adulteration $(6 ; 4,2 ; 7 ; 8)$. The microbial load may increase up to 100 fold or more once the milk is stored for some time at ambient temperature (9). The growth of microorganisms in milk causes disintegration of fat, protein and lactose and also makes the product unsuitable for drinking (10).

Milk being a major constituent of human diet, can serve as a good medium for the growth of many microorganisms especially bacterial pathogens, therefore its quality control is considered essential to the health and welfare of a community. As reported by Foster (11), the threat posed by diseases spread through contaminated milk is well known and the epidemiological impact of such diseases is considerable. The presence of these pathogenic microorganisms in milk has emerged as a major public health concern especially for those individuals who still drink raw milk. The aim of this work therefore is to determine the microbiological quality of raw milk from different locations in Abia state and also to compare the microbial quality of the milk from a controlled environment (Michael Okpara University of Agriculture, Umudike) to others from commercial source

\subsection{Collection of samples}

\section{Materials And Methods}

Four milk samples from four locations in Abia State were analyzed in this work. The samples were gotten from Michael Okpara University of Agriculture animal farm Umudike, Lokpa, Umuahia and Aba, all in Abia state of Nigeria. The samples were aseptically collected using sterile universal bottle. The samples were transported in ice-packed flask to the laboratory. 


\subsection{Isolation and enumeration of microorganisms.}

Nutrient agar (NA), MacConkey agar (MCA), Sabouraud dextrose agar (SDA) and Mannitol salt agar (MSA) used in this work were prepared according to the manufacturer's direction. After preparation, the media were autoclaved at $121^{\circ} \mathrm{C}$ at $15 \mathrm{KPa}$ for $15 \mathrm{mins}$ and allowed to cool before been poured into petri dishes. Ten fold serial dilution of each sample was prepared and using a sterile micropipette, $0.1 \mathrm{ml}$ was collected from the $4^{\text {th }}$ diluent and inoculated onto the MCA, MSA and SDA plate for Coliform count, Staphylococcal and fungal count respectively. $0.1 \mathrm{ml}$ was also collected from the $5^{\text {th }}$ diluent and inoculated onto the NA, for total heterotrophic count. They were inoculated using a spread plate technique. The inoculated plates were inverted in an incubator at $37^{\circ} \mathrm{C}$ for $24-48 \mathrm{~h}$ except SDA plates that were incubated at $25^{\circ} \mathrm{C}$ for at least $72 \mathrm{~h}$. The plates were then observed for colony formation.

\subsection{Identification of the isolates}

The identification of the bacteria was based on the description of (12) and (13) and was done using standard cultural, morphological and biochemical tests. The tests included; Gram reaction, motility, catalase, oxidase, coagulase, indole and sugar fermentation.

The associated fungi were identified as described by (14 and 15).

\section{Results And Discussion}

In this investigation, three bacteria genera and two fungal species (Escherichia coli, Staphylococcus aureus, Streptococcus spp, Mucor spp. and Candida spp) were isolated in the milk produced in the aforementioned locations in Abia State (TABLE 2). This agrees with the work of (16) and (17) who reported similar organisms in milk and milk products. The work differed slightly from the results of (8) and (18) who observed Bacillus spp, Pseudomonas spp and other Enterobacteriaceae in their work, the observed differences could be due to environmental differences, climatic conditions, $\mathrm{pH}$ or even the human beings involved.

Generally, the presence of these organisms in milk can be related to factors such as use of contaminated water, health of the animal, use of unsanitized milking equipment, health of milking personnel, milking environment, poor hygiene feeding and housing strategies of cows, etc. $(7,8,16)$.

Among the organisms isolated, all the bacteria (Escherichia coli, Staphylococcus aureus and Streptococcus spp) had $100 \%$ occurrence, being present in all test samples, while the two fungal isolates were $75 \%$ each and were not present in all the test samples (TABLE 2.)

According to the result, the heterotrophic bacteria count was high and falls within the range of $9.88 \mathrm{x}$ $10^{7}$ to $1.26 \times 10^{8} \mathrm{cfu} / \mathrm{ml}$ (TABLE 1). It was assumed that most of these bacteria isolates have the capacity to cause diseases like food poisoning, gastroenteritis and mastitis. However some of these microorganisms can be prevented from causing disease in humans since milk is usually pasteurized or treated before consumption. The presence of pathogens in milk emerges as a public health concern, especially for those individuals who still drink raw milk (17).

The coliform count was also high and they were isolated in all the samples (TABLES 1 and 2). The isolation of coliforms from raw milk sample might be related to the closeness of the udder to the anus of the animal since they are normal flora of the intestine. Also there is the tendency of the udder and the teat to be contaminated or dirtied by the animal dung when they lie down on it. With E.coli being an important member of the coliform bacteria, its presence suggests that other enteric pathogens like Salmonella spp, Shigella, spp, Vibrio cholera, Campylobacter spp and also some enteric protozoa, etc. may also be present in the test sample. Some strains of E.coli can cause gastroenteritis, urinary tract infection as well as diarrhoea in infants.

S. aureus which is a normal flora of the skin and mucus membrane was also present in high numbers and ranged from $6.7 \times 10^{7}$ to $1.07 \times 10^{8} \mathrm{CFU} / \mathrm{ml}$ (TABLE 1). Streptococcus spp was also isolated from the milk sample (TABLE 2). These two organisms have been incriminated as sole cause of mastitis, with $S$. aureus being the most common etiological agent responsible for the disease. Mastitis is the inflammation of the breast tissues and occurs in domestic animals as in human beings, and is especially a concern in livestock, since milk from the affected udders of the live stock may enter the food supply and pose a health risk. It is a major condition in dairy cow and has a tremendous economic importance for the dairy industry. Apart from mastitis, the presence of $S$. aureus in food causes food poisoning (15). Also S. aureus has been linked to infections like boils, skin infections, deep abscesses and meningitis in debilitated persons and causes gastroenteritis by producing enterotoxins, (19).

The presence of fungal isolates suggests that not only bacteria can be found in milk. Mucor species which has a world-wide distribution but mostly found in soil, dung etc was isolated. Mucor spp are known to cause diseases in man and animal. Mucor racemosus is often found in milk and other food products. Candida spp also found in milk sample causes many human and animal diseases, despite being the normal flora of the skin. This yeast has been implicated in some milk related diseases by some other researchers (20). Their presence in milk though in low numbers, might be a public health concern. 
Comparing the microbial quality of raw milk samples collected from the university farm to the others from other locations, the university farm's samples have lower microbial load. The microbial load variation in these samples can be attributed to the aseptic measures applied during milking in the university farm which may not be applied to the ones from the other locations. Also adequate care, treatment of the animals, and regular check up of the animals in the campus by veterinary doctors and animal scientists goes a long way to reduce infections in these animals. According to (16) differences in feeding and housing strategies of cows may influence the microbial quality of milk.

\section{Conclusion And Recommendation}

In conclusion, high microbial counts and the occurrence of pathogens are likely to affect the keeping quality and safety of raw milk as well as products derived from it. The achievement of hygiene in dairy farm directly influences the production oriented economic results and health safety perspective in human beings.

It is therefore recommended that the animals be treated by experts to ensure the health of the animals. Also public health training and guidance should be given to farmers, and their workers. Meanwhile, information on health hazards associated with contaminated raw milk should be extended to the public so that consumption of untreated/improperly treated raw milk could be avoided.

\section{References}

[1] S.B. Javaid, J.A. Gadahi, M. Khaskeli, M.B. Bhutto, S. Kumbher and A.H. Panhwar, Physical and chemical quality of market milk sold at Tandojam, Pakistan. Pakistan Veterinary Journal. 29(1), 200), $27-31$.

[2] M.L. Srivastava, Handbook on milk microbiology, (Delhi: Daya Publishing house, 2002) 216pp

[3] N.N. Potter and J.H. Hotchkiss, Food science 5th ed. (New York Chapman and Hall ITP,1995) 279.

[4] R. Lawley, Liquid milk products, LFRA Microbiology Handbook :Dairy products, $2^{\text {nd }}$ ed. (Surrey,UK: Leather head food Research Association, 2001) 1-15

[5] K.P.Talaro, Foundations in Microbiology $5^{\text {th }}$ ed. (New York: McGraw-hill Higher education, 2005) 815-817.

[6] S.C Murphy and K.J. Boor, Trouble shooting sources and causes of high bacteria counts in milk, Dairy food environmental sanitation, 20, 2000, 606-611.

[7] D.R. Arora, Bacteriology of milk. Text book of Microbiology 2nd ed. (New Delhi, India: CBS Publishers and Distributors, 2003). $656 \mathrm{pp}$.

[8] B. Bonfoh, A. Wasem, A.N. Traore, A. Pane, H. Spillman, C.F. Simbe, J.O. Alfaroukh, J. Nicolet, Z. Farah and J. Zinsstag, Microbiological Quality of cow's milk taken at different intervals in Bamako Mali, Food Control. 14(17), 2003, 495-500.

[9] R.L. Richter, R.A. Ledford and S.C. Murphy, Milk and milk products, in C. Vanderzant and D.F.(Splittstoesser, (Ed.),Compendium of methods for the microbiological examination of foods. 3rd ed (Washington DC. American Public Health Association,1992) 837838 .

[10] E.T. Ryser Public health concerns, in E.H. Marth and J.L.Steele (Ed) Applied Dairy Microbiology (New York: Marcel Dekker Inc, 1998) 263-403

[11] E.M. Foster, Perennial issues in food safety. in D.O. Cliver, (Ed.) Food-borne disease. (San Diego: Academic press, 1990) 369-381.

[12] M. Cheesbrough, District Laboratory practice in Tropical countries (part 2) Low price ed. (United Kingdom: Cambridge University Press, 2000), 46-70.

[13] C.I. Barrow and R.K.A. Feltham, Cowan and Steel's Manual for the Identification of Medical Bacteria 3rd Ed. (London: Cambridge University Press, 2003), 331pp

[14] W.C. Frazier and D.C Westhoff, Food Microbiology 4th ed (New Delhi: Tata McGraw hill Publishing company Limited, 1995) 276299.

[15] H.L. Barnett and B.B. Hunter, Illustrated genera of Imperfect fungi. $2^{\text {nd }}$ ed. (Minneapolis: Minneapolis Burgress Publishing Co.,1972). pp 241

[16] K.G. Torkar and S.G. Teger, The Microbiological quality of raw milk after introducing the two days milk collecting system, Acta Agricultura Slovenica, 92 (1): 2008, 61-74.

[17] M.H. Mubarack, A. Doss, R. Dhanabalan and S. Balanchander, Microbial quality of raw milk samples collected from differentvillages of Coimbatore district, Tamilnadu, South India, Indian Journal of Science and Technology. 3(1), $2010,61-63$.

[18] B.C. Nangamso, General Hygiene of commercially available milk in the Bloemfontein area. (Bloemfontein, South Africa: University free state, 2006) 1-126.

[19] J. Okpalugo, K. Ibrahim, K.S. Izebe and U.S. Inyang, Aspects of microbial quality of some milk products in Abuja, Nigeria, Tropical Journal of Pharmaceutical Resources 7(4), 2008, 1169-1177.

[20] G.H. Fleet, Yeast in Dairy products: A review. Journal of Applied Bacteriology. 68, 1990, $199-211$.

Table 1: The Microbiological count of the milk samples (cfu/mL)

\begin{tabular}{llccc}
\hline Sample & $\begin{array}{c}\text { Total heterotrophic count } \\
\text { (NA) }\end{array}$ & $\begin{array}{c}\text { Coliform count } \\
(\mathrm{MCA})\end{array}$ & $\begin{array}{c}\text { Staphylococcal count } \\
(\mathrm{MSA})\end{array}$ & $\begin{array}{c}\text { Fungal count } \\
\text { (SDA) }\end{array}$ \\
\hline Umudike & $9.88 \times 10^{7}$ & $5.40 \times 10^{6}$ & $6.70 \times 10^{7}$ & $6.90 \times 10^{7}$ \\
Lokpa & $1.26 \times 10^{8}$ & $9.50 \times 10^{6}$ & $10.70 \times 10^{7}$ & $9.20 \times 10^{7}$ \\
Umuahia & $1.11 \times 10^{8}$ & $8.00 \times 10^{6}$ & $9.90 \times 10^{7}$ & $7.00 \times 10^{7}$ \\
Aba & $1.17 \times 10^{8}$ & $6.60 \times 10^{6}$ & $9.50 \times 10^{7}$ & $6.40 \times 10^{7}$ \\
\hline
\end{tabular}


The Microbial Quality of Raw Milk from four locations in Abia State, Nigeria

Table 2: Percentage occurrence of microbial isolates

\begin{tabular}{llllll}
\hline Sample & E. coli & S. aureus & Streptococcus spp & Candida spp & Mucor spp \\
\hline Umudike & + & + & + & + & - \\
Lokpa & + & + & + & + & + \\
Umuahia & + & + & + & + & + \\
Aba & + & + & + & - & + \\
$\%$ occurrence & 100 & 100 & 100 & 75 & 75 \\
\hline
\end{tabular}

